\title{
INVASIVE ORCHIDS: WEEDS WE HATE TO LOVE?
}

\author{
JAMES D. ACKERMAN \\ Department of Biology, University of Puerto Rico \\ PO Box 23360 \\ San Juan PR 00931-3360, U.S.A. \\ jdackerman@uprrp.edu
}

Rare species that show habitat specificity and an aversion to habitat disturbance may be common in the Orchidaceae (Tremblay et al. 1998; Bergman et al. 2006). Nonetheless, most orchids may not be in such a critical state and many are, quite frankly, weedy. We may learn much about rare species by asking what makes other orchids common and resilient or actually dependent on change. Most orchids do occur in ephemeral or frequently disturbed habitats (Ackerman 1983; Catling 1996) whether they are pastures, roadsides, citrus groves, coffee and tea farms, or simply as epiphytes whose substrates, by definition, are temporary and run the gamut from durable tree trunks to short-lived twigs (Johansson 1974).

Effective dispersal capabilities are essential for occupying ephemeral habitats. Certainly orchid seed morphology lends itself to the possibility of distance dispersal (Arditti \& Ghani 2000; Murren \& Ellison 1998). In the West Indies, nearly $60 \%$ of the orchid species occur on more than one island and a floristic affinity analysis has indicated that geographical distance for these species is generally not a barrier to dispersal (Trejo-Torres \& Ackerman 2001).

The combination of mobility and widespread preference for ephemeral habitats appears to have given orchid populations a degree of resiliency that is generally underappreciated. We all know that deforestation, or habitat destruction is a common problem not only in the tropics but elsewhere throughout the world. A prime example is Puerto Rico where $95 \%$ of the forest cover was cut by the early 1940's (Brash 1987; Lugo et al. 1993 cited by Figueroa Colón 1996), yet the number of orchid species lost from the flora has been less than 5\%. Since then, forest recovery has been substantial and some orchid species have responded positively to the re-growth, a few becoming quite abundant in secondary habitats (Ackerman \& Galarza-Pérez 1991).

Orchids with rapidly expanding populations include natives, but non-natives everywhere are making their appearance (Table 1). In fact, the global compendium of weeds (www.hear.org/gcw/ index.html) lists over 90 orchid weeds! In Puerto Rico, a number of non-native orchids have persisted for a long time, but only recently have they become aggressive taking on weed-like characteristics. Such a demographic pattern is very typical of invasive species.

What makes an orchid weedy and invasive? Many plants that are classified as weeds have a suite of characteristics associated with colonization capabilities, and some of these features characterize orchids in general: abundant seed production (although in orchids effective population sizes may be small), distance dispersal, and weak competitive capabilities. Rapid development, autogamy and apomixis are also common features of weeds, but these are certainly not common features of orchids. From a sample of weedy orchids, we find a complete spectrum of breeding systems (e.g., Sun 1997), from apomictic or autogamous to outcrossing, and plants of the latter may be either self-compatible or -incompatible.

It is difficult to find a common thread among the invasive orchids. Some are understory plants; perhaps most prefer grassy roadsides, while a few others are epiphytes. Some are autogamous but others attract local pollinators with nectar rewards or by deceit, with pollination systems not unlike that of local species. Answers may rest not only with the distribution of appropriate habitat, but also with the 
TABLE 1. Orchid species naturalized in Puerto Rico.

\begin{tabular}{|c|c|c|c|c|}
\hline Species & Native & Non-native & Breeding system & Habitat \\
\hline Arundina graminifolia & $\begin{array}{l}\text { India, Nepal, China, SE } \\
\text { Asia to Indonesia }\end{array}$ & $\begin{array}{l}\text { Hawaii, Puerto Rico, } \\
\text { Guadeloupe }\end{array}$ & $\begin{array}{l}\text { Outcrossing } \\
\text { Deception }\end{array}$ & Open disturbed \\
\hline Dendrobium crumenatum & $\begin{array}{l}\text { India, Bangladesh, } \\
\text { China, Burma, Thailand, } \\
\text { Vietnam, Indonesia, } \\
\text { Malaysia, Philippines, } \\
\text { Australia }\end{array}$ & $\begin{array}{l}\text { Puerto Rico, } \\
\text { Guadeloupe }\end{array}$ & Outcrossing reward & Open \\
\hline Epidendrum radicans & $\begin{array}{l}\text { Mexico, Central } \\
\text { America, Colombia }\end{array}$ & Cuba, Puerto Rico & $\begin{array}{l}\text { Outcrossing } \\
\text { deception }\end{array}$ & Open disturbed \\
\hline Oeceoclades maculata & Africa & $\begin{array}{l}\text { South America, } \\
\text { Central America, } \\
\text { West Indies, Florida }\end{array}$ & Autogamous & Shady \\
\hline Phaius tancarvilleae & $\begin{array}{l}\text { India, Nepal, China, SE } \\
\text { Asia to Phillipines, South } \\
\text { Pacific Islands }\end{array}$ & $\begin{array}{l}\text { Hawaii, Cuba, } \\
\text { Jamaica, Puerto Rico }\end{array}$ & $\begin{array}{l}\text { Outcrossing? } \\
\text { Deception }\end{array}$ & Open to shady disturbed \\
\hline Spathoglottis plicata & $\begin{array}{l}\text { India, SE Asia New } \\
\text { Guinea, New Caledonia } \\
\text { to Phillipines }\end{array}$ & $\begin{array}{l}\text { Hawaii, Cuba, Puerto } \\
\text { Rico, Virgin Islands, } \\
\text { Lesser Antilles }\end{array}$ & Autogamous & Open, disturbed ground \\
\hline Vanilla planifolia & $\begin{array}{l}\text { Mexico, Central } \\
\text { America? }\end{array}$ & $\begin{array}{l}\text { Puerto Rico, West } \\
\text { Indies, Central \& } \\
\text { South America }\end{array}$ & Outcrossing deception* & Forest disturbed habitats \\
\hline Vanilla pompona & $\begin{array}{l}\text { Mexico, Central } \\
\text { America, South America }\end{array}$ & $\begin{array}{l}\text { Puerto Rico, Lesser } \\
\text { Antilles? }\end{array}$ & Outcrossing deception* & Forest disturbed habitats \\
\hline Zeuxine strautematica & $\begin{array}{l}\text { Sri Lanka, India, SE } \\
\text { Asia, Java, Phillipines, } \\
\text { Taiwan, Japan }\end{array}$ & $\begin{array}{l}\text { Southern USA, } \\
\text { Bahamas, Cuba, } \\
\text { Jamaica, Puerto Rico }\end{array}$ & Apomictic & Open disturbed \\
\hline
\end{tabular}

*The two vanillas may be reward plants at least for the male euglossine bee pollinators in Central America.

players in the orchids' symbiotic relationships: pollinators and mycorrhizal fungi. Widespread species either specialize on widespread "partners" or are catholic with whom they play or exploit (cf. Bascompte et al. 2003; Vázquez \& Aizen 2004). The asymmetrical relationship between plants and their pollinators is well documented, but the relationship between orchids and their mycorrhizal symbionts is only just beginning to be revealed (e.g., Otero et al. 2002, 2004; Taylor et al. 2003). What do rare species do? Again, we do not know this entirely but we can predict that constraints of specificity may have a role, whether it is the habitat, the pollinators, their mycorrhizal associations, or some combination of the three remains to be seen.

Finally, we are faced with an orchidaceous dilem- ma: can non-native, marquee taxa be so bad? Do they exclude native taxa or disrupt natural ecosystems or are they benign? Do we encourage, tolerate or fight such intrusions to our sovereign soil?

\section{Literature Cited}

Ackerman, J.D. 1983. On the evidence for a primitively epiphytic habit in orchids. Syst. Bot. 8: 474-477.

Ackerman, J.D., J.C. Trejo Torres \& Y. Crespo Chuy. In press. Orchids of the West Indies: predictability of diversity and endemism. J. Biogeography.

Ackerman, J.D. \& M. Galarza-Pérez. 1991. Patterns and maintenance of extraordinary variation in the Caribbean orchid, Tolumnia (Oncidium) variegata. Syst. Bot. 16: 182-194.

Arditti, J. \& A.K.A. Ghani. 2000. Numerical and physical properties of orchid seeds and their biological 
implications. New Phytol. 145: 367-421.

Bascompte, J., P. Jordano, C.J. Melián \& J.M. Olesen. 2003. The nested assembly of plant-animal mutualistic networks. Proc. Nat. Acad. Sc. (USA) 100: 93839387.

Bergman, E., J.D. Ackerman, J. Thompson \& J.K. Zimmerman. 2006. Land use history affects the distribution of the saprophytic orchid Wullschlaegelia calcarata in Puerto Rico. Biotropica 38: 492-499.

Brash, A. 1987. The history of avian extinction and forest conversion on Puerto Rico. Biol. Conserv. 39: 97-111.

Catling, P.M. 1996. Conservation strategy. Pages 11-23 in: IUCN/SSC Orchid Specialist Group, Orchidsstatus survey and conservation action plan. IUCN Gland, Switzerland and Cambridge, UK.

Figueroa Colón, J.C. 1996. Phytogeographical trends, centers of high species richness and endemism, and the question of extinctions in the native flora of Puerto Rico. Ann. New York Acad. Sc. 776: 89-102.

Johansson, D. 1974. Ecology of West African epiphytes. Acta Phytogeog. Suec. 59: 1-129.

IUCN/SSC Orchid Specialist Group. 1996. Orchidsstatus survey and conservation action plan. IUCN Gland, Switzerland and Cambridge, UK.

Lugo, A., J. Parrotta \& S. Brown. 1993. Loss in species caused by deforestation and their recovery through management. Ambio 22(2-3): 106-109.

Murren, J.C. \& A.M. Ellison. 1998. Seed dispersal char- acteristics of Brassavola nodosa (Orchidaceae). Amer. J. Bot. 85: 675-680.

Otero J.T., J.D. Ackerman\& P. Bayman. 2002. Diversity and host specificity of endophytic Rhizoctonia-like fungi from tropical orchids. Amer. J. Bot. 89: 1852-1858.

Otero J.T., J. D. Ackerman \& P. Bayman. 2004. Differences in mycorrhizal preferences between two tropical orchids. Molec. Ecol. 13: 2393-2404.

Sun, M. 1997. Genetic diversity in three colonizing orchids with contrasting mating systems. Amer. J. Bot. 84: 224-232.

Taylor, D.L., T.D. Bruns, T.M. Szaro \& S.A. Hodges. 2003. Divergence in mycorrhizal specialization within Hexalectris spicata (Orchidaceae), a nonphotosynthetic desert orchid. Amer. J. Bot. 90: 1168-1179.

Trejo-Torres, J.C. \& J.D. Ackerman. 2001. Biogeographic affinities of Caribbean Orchidaceae based on parsimony analyses of shared species. J. Biogeogr. 28: 775-794.

Tremblay, R.L., J.K. Zimmerman, L. Lebrón, P. Bayman, I. Sastre, F. Axelrod \& J. Alers-García. 1998. Host specificity and low reproductive success in the rare endemic Puerto Rican orchid Lepanthes caritensis (Orchidaceae). Biol. Conserv. 85: 297-304.

Vázquez, D.P. \& M.A. Aizen. 2004. Asymmetric specialization: a pervasive feature of plant-pollinator interactions. Ecology 85: 1251-1257.

James D. Ackerman is Professor of the University of Puerto Rico at Río Piedras. He is a biologist with broad interests, but focuses on the ecology, systematics and evolution of Orchidaceae. His present interests include studies on the relationship between land use history and orchid distributions, orchid biogeography, invasive orchids, and their mycorrhizal relationships. 